\title{
Representation of Media Literacy of Health Communication Dimensions in Indonesia
}

\author{
Kinkin Yuliaty Subarsa Putri \\ Public Relation \\ Faculty of Social Science \\ Jakarta State University \\ Jakarta, Indonesia \\ kinkinsubarsa@unj.ac.id
}

\author{
Vera Wijayanti Sutjipto \\ Public Relation \\ Faculty of Social Science \\ Jakarta State University \\ Jakarta, Indonesia \\ verawijayanti@unj.ac.id \\ S. Bekti Istiyanto \\ Faculty of Social and Political Science \\ Jenderal Soedirman University \\ Purwokerto, Indonesia \\ bektiis@yahoo.com
}

\begin{abstract}
Health in Indonesia is not so good move. One factor is the lack of information and socialization of health programs to the community. This study looks from previous research states that information has been submitted to the community in the media below the line. But the public literacy is not so good. So, the information that has been submitted not to the community. Research on health communication pattern in service and giving information about TB disease at puskesmas in Bogor Regency by Kokom's team. Health communication partnership M/MC health communication is the art and technique of disseminating health information that intends to influence and motivate the individual, encouraging the birth of an institutional institution either as a regulation or as an organization among audiences that regulate health concerns (Liliweri, 2007: 47). The method used is deep interview and observations. The results of this study show descriptively that the community has not understood the meaning and purpose that is delivered in all forms of health information submitted by the government. In depth, society still adheres to the values that are received down and down from the family. So however what keeps myth in maintaining health. The suggestion in this research is to use other method with prediction in health communication in Indonesian society.
\end{abstract}

Keywords - health communication; environment health; media of health communication

\section{INTRODUCTION}

New media is very helpful to society today. New media provides both positive and negative benefits. Along with that, the element of human need accompanies it. Including health side. Indonesia still has a not so good health figure. According to data from the Ministry of Health the number and casualties of health crisis events in Indonesia In 2017 with frequency as much as 197, died as many as 198, serious injuries / hospitalization as much as 2,314, minor injuries / outpatient as much as 63,578, and 239.747 evacuee [1].

New media can help all the information and health needs of the community. But people use new media only for the present information only. Not to seek the necessary health needs. New media used by almost all people of Indonesia.

Mobile phone users (mobile) in the country reached 371.4 million users or 142 percent of the total population of 262 million people. That is, on average each resident uses 1.4 cell phones because one person sometimes uses 2-3 mobile phone cards. While the urban Indonesia reached 55 percent of the total population. [2].

Based on data wearesocial.sg, internet users in Indonesia reached 132.7 million with penetration of about 51 percent of the population. For active social media users it reaches 106 million with a penetration of about 40 percent, and active mobile social media users reach 92 million or about 35 percent of the population. Compared to the position in January 2016, Indonesian mobile phone users increased 14 percent. As for penetration of active social media use increased 34 percent, and the penetration of active mobile social media users increased 39 percent [2].

Based on data from the Ministry of Education and Culture on education data according to the level of education in 2016/2017 is at the level of Kindergarten (TK) as many as 4.605.809 students, at the level of Extraordinary School (SLB) as many as 121,244 students, at elementary school level as 
many as 25,618,078 students, at 10,145,416 students of Primary School (SMP), at the level of High School of $3,659,542$ students, and in Vocational High School as many as $4,682,913$ students [3].

\section{Previous Research Studies}

Previous research has been done by Kokom Kumariah and colleagues with the title of Communication Pattern of Health in Service and Provision of Information about Tuberculosis Disease at Puskesmas in Bogor Regency, 2013 [4]. Then by Kinkin and friends with the title Representation of Media Literacy in the Dimension of Social Life in Indonesia. Then in ISKI journal by Puji Rianto with the title of New Media, Active Audience Vision and Urgency of Media Literacy [5].

The understanding of media literacy is traditionally defined as an ability to access, analyze, and create. According to Brown, media literacy is the ability to analyze and appreciate literary works, and to communicate effectively through good writing. Ferrington describes the understanding of media literacy in the expanded seventies including the ability to read film, television and visual media texts because the study of media education began by following the development of the media area. Meanwhile, according to Hobbs, media literacy is the process of accessing, critically analyzing media messages and creating messages using media tools. Rubin explains that what is meant by media literacy is the understanding of the source, the communication technology, the code used, the resulting message, the selection, the interpretation and the impact of the message.

The two most common components of the definition of media literacy are the awareness of many media messages and critical ability to analyze and question what is seen, read and watched. Five concepts of media literacy under the Center of Media Literacy are as follows: all media messages are "constructed"; media messages are constructed in a creative language according to their rules; individuals interpret the message depending on their understanding of the message they are capturing from the media; media has a point of view and contains its own value; almost all media messages have a vested interest or power.

The term promotions has always been linked to sales, advertising, and is seen as a propaganda approach dominated by mass media use. In the context of health, promotion is an effort to improve health by promoting, supporting, and placing health higher than the agenda, either individually or in groups. The main determinants of health are the economic, social and environmental aspects that are often beyond the control of individuals or communities collectively.

Therefore, the fundamental aspect of health promotion is empowerment so that individuals are better able to control aspects of their life that affect health. According to this understanding, there are two elements of the objective and process of health promotion activities, which is to improve health and have greater control over it (aspects of life that affect health).

The WHO definition, based on the Ottawa / Ottawa charter (1986) charter on health promotion, emphasizes that health promotion is a process aimed at enabling individuals to increase health control and improve their health based on a clear philosophy of self-empowerment. The process of devotion is carried out from, by, for, and with the community and in accordance with the local social culture. Health promotion not only increases the "awareness" and "will" as connoted in health education. In order to achieve a perfect degree of health, both physically, mentally and socially, the community must be able to recognize and realize its aspirations and needs, and be able to change or overcome the physical, socio-cultural and economic environment, including policies and laws.

Some definitions focus on activities, while others focus on goals. One of the definitions that focus on promotional activities emerging from Green \& Ottoson health promotion is a combination of educational, organizational, policy, and regulatory support for environmentally beneficial environmental and behavioral changes. This limitation emphasizes that health promotion is a comprehensive community program, not just behavioral change, but also environmental change. Behavioral changes without environmental change will not be effective, and also certainly will not last long. For example, the prohibition of not littering will not be effective if there are not enough bins available, either in quantity, distance, or shape. Therefore, health promotion is not just changing behavior. However, health promotion also seeks changes in the environment, systems, and health policies.

According to Ewles and Simnett, there are six core competencies in health promotion. The first is to manage, plan, and evaluate. In health promotion, it is important for health workers to have the ability to manage health promotion resources, including money, materials, self, and others. Systematic planning is required for effective and efficient promotion. All health promotion activities also require evaluation, and different and appropriate methods for different approaches.

The second competence is Communication. Health promotion is about people so that communication competence becomes important and fundamental. This competence is required in intrapersonal, interpersonal, and community communication in various ways, both formal and informal.

The third competency is education. Health education requires good communication, in addition to requiring additional educational competencies so that a health educator can work in different places in choosing and using appropriate strategies for different educational purposes. Educational competence is clearly important in health promotion programs in addition to being used in other forms of activities.

The fourth competency is marketing and publication. Health promoters require competence in marketing and publications. This is useful when undertaking promotional activities that provide significant benefits through widespread publicity.

The fifth competence is the facility and network. Health promotion is the process of community empowerment. The important thing when working with a community is the ability 
to facilitate and build a network so that others can promote their own health and others. This effort can be done in various ways, such as the exchange of skills and information, and build confidence in yourself and others.

The sixth competence is influencing policy and practice. Health promoters are actually in businesses that affect policies and practices. In order to influence policy and practice, we need to understand the distribution and application of power in communities at various levels, and be able to use their knowledge to influence decisions. This includes working with various organizations to influence them to develop policies that support the health status of their staff and produce healthenhancing products and services. Health promoters can also play a role in developing sound public policies, economic changes, and regulations that require lobbying and political action.

\section{RESEARCH METHOD}

The research used qualitative research method. Creswell's qualitative approach is an approach to exploring and understanding a central phenomenon. To understand the central phenomenon researchers interview participants or participants by asking general and rather broad questions. Information submitted by participants is then collected. The information is usually word or text. The data in the form of words or text is then analyzed. The results of the analysis can be either a description or description or it can be in the form of themes. From the data the researchers make interpretations to capture the deepest meaning. Afterward, the researcher makes selfreflection and describes it by the observation of other scientists made before. Qualitative final outcomes are outlined in the form of a written report. [6, p. 7]

Everyone gives meaning to everything that will control their actions. The idea of symbolic interactionism is a way of thinking about the mind (mind), self and society. Sociology as the foundation, this understanding teaches that when humans interact with each other, they share meaning for a certain period of time and for a particular action.

Symbolic interactionism focuses on the ways in which humans make meaning and structure of society through conversation. 'A symbolic behavior that raises various levels of meaning and shared value among its participants. [7, pp. 224225]

Symbolic interaction theory bases its ideas on three important themes namely the importance of meaning in human behavior, the importance of self-concept, and the relationship between individuals and society. These three important themes produce the following seven assumptions that humans behave based on the meaning that others give to themselves. Meanings are created through interaction between humans. The meaning undergoes modification through the process of interpretation. Humans develop self-concept through interaction with others. Self-concept becomes an important motive for behavior. Humans are influenced by cultural and social processes. Social structures are formed through social interaction. Blumer mentioned that in developed societies most of the group's actions consist of repetitive and stable patterns that have shared and established meaning for the members of the community. [7, p. 225]

The idea of this social action in our minds, now let us look more closely at the first aspect of Herbert Mead's analysis of society. Society can be realized or formed by the existence of these significant symbols. Because of the human ability to pronounce symbols we can also listen to ourselves and respond to ourselves as others respond to us. [7, p. 225]

Key informants of this research are the head of Bayah Banten Sub-district, Banten Suyanto S.I.P and informants from Bayah Banten and Jakarta community and head of Lebak health office, Banten HM Sukirman. And head of district Jakarta, Tebet Barat, and Kayumanis..

\section{RESEARCH RESULT}

The results of this study show information about health presented by the district health office Lebak, Banten HM Sukirman states that the health office Lebak Banten has to update and update all information that is ordered by the central government. Also needs information needed by the people of Lebak district, Banten. Whether through new media or regular meetings with citizens. The socialization of health information is also supported by the local government, the district of Bayah, Banten.

The people of Bayah and Jakarta are among those who obey what the local leaders say. The people come every time the sub-district and the head of the region ask the community to be present in every socialization of health information. But the community is less responsive in any information submitted by the officers.

In Jakarta has a Qlue system, where people can get information and ask about community service. But again people do not optimize the positive usability of this system. Communities in these two areas have a response to new media is very good. However, media literacy on media content presented is not yet optimal in use in public life.

\section{DISCUSSIONS}

The results of this study strongly illustrate the characteristics of society that the relevance of new media and public health needs have not been used optimally. From some previous research, in some regions in Indonesia and outside Indonesia showed that people still growing at the level of ownership and new media features are used. But in terms of media content has not been optimally used by the community. So many new media also provide hoax information, so the lazier people also to trust the contents of new media as well.

\section{CONCLUSIONS AND RECOMMENDATIONS}

New media is needed by the community. The new media content for users should be tailored for the user. Health information has been provided by health workers through new media and traditional media. And has been distributed to all regions in Indonesia. But the contents of the new media have not been optimized by new media users. 
Suggestion of this research is education activity for Indonesian society in health information in new media should always be done at academic level, research and service to society. In order for the community to always be aware and action in understanding the contents of new media about health information.

\section{REFERENCES}

[1] Ministry of Health of the Republic of Indonesia, Data dan Informasi Profil Kesehatan Indonesia 2017 [Data and Information of Indonesia's Health Profile 2017]. [Online]. Available: http://www.depkes.go.id/resources/download/pusdatin/profil-kesehatanindonesia/Data-dan-Informasi_Profil-Kesehatan-Indonesia-2017.pdf. [Accessed May 20, 2018].

[2] "Pengguna Ponsel Indonesia Mencapai 142\% dari Populasi [Indonesian Cellphone Users Reached $142 \%$ of its Population],” Katadata.co.id. [Online]. Available: https://databoks.katadata.co.id/datapublish/2017/08/29/penggunaponsel-indonesia-mencapai-142-dari-populasi. [Accessed May 20, 2018].
[3] Ministry of Education and Culture of the Republic of Indonesia, Ikhtisar Data Pendidikan Tahun 2016/2017 [Summary of Education Data, Year 2016/2017]. [Online]. Available: http://publikasi.data.kemdikbud.go.id/uploadDir/isi_FC1DCA36-A9D84688-8E5F-0FB5ED1DE869_.pdf.

[4] K. Komariah, S. Perbawasari, A. R. Nugraha, and H. R. Budiana, "Pola Komunikasi Kesehatan dalam Pelayanan dan Pemberian Informasi Mengenai Penyakit TBC pada Puskesmas di Kabupaten Bogor [Health Communication Pattern in Service and Information Handouts about TBC Disease at Public Health Center in Bogor Regency],” Jurnal Kajian Komunikasi, vol. 1, no. 2, pp. 173-185, 2013.

[5] P. Rianto, "Media Baru, Visi Khalayak Aktif dan Urgensi Literasi Media [New Media, Active Public Vision and Media Literacy Urgency]," Jurnal Iski, vol. 1, no. 20, pp. 90-96, 2016.

[6] J. R. Raco, Metode Penelitian Kualitatif: Jenis, Karakteristik, dan Keunggulannya [Qualitative Research Method: Types, Characteristics, and its Superiorities]. Jakarta: PT. Gramedia Widiasarana, 2010.

[7] Morissan, Teori Komunikasi: Individu Hingga Massa [Communication Theory: Individual to the Masses]. Jakarta: Kencana Prenadamedia Group, 2013 